PAEDAGOGIA CHRISTIANA

2/26(2010) - ISSN 1505-6872

\title{
Dialog młodych w doświadczeniu Wspólnoty ekumenicznej z Taizé - wywiad z Bratem Markiem z Taizé
}

Taizé jest miejscem, w którym zbierają się młodzi ludzie ze wszystkich kontynentów. Jest to środowisko dialogu młodych, z młodymi i o młodych; dialogu, w którym nie przemilcza się różnic między różnymi sposobami postrzegania świata, człowieka i Boga. Mając świadomość, że praktyka dialogu prowadzi do wielu interesujących doświadczeń, odsłania możliwości, jakie rodzi dialog, ale także daje szansę dostrzeżenia trudności związanych z dialogiem, chcielibyśmy prosić Brata o podzielenie się doświadczeniami dialogu, którym żyje Wspólnota z Taizé.

- Jerzy Bagrowicz, Jarosław Horowski: Na początek prosilibyśmy o krótkie wprowadzenie naszych czytelników w historię Wspólnoty z Taizé, gdyż pozwoli to na osadzenie refleksji nad dialogiem w Taizé w konkretnych uwarunkowaniach historycznych.

- Brat Marek: Brat Roger myślat od poczatku o wspólnocie, która na co dzień będzie żyła sprawa pojednania i modlita się o pokój na świecie. Rozumiat, że pojednanie chrześcijan jest warunkiem zapanowania pokoju. O dostrzeżeniu tego problemu zadecydowato niewatpliwie doświadczenie jego babki. Pochodziła ona ze starego rodu protestanckiego, ale $w$ czasie I wojny światowej zaczęła chodzić do Kościoła katolickiego na Eucharystię, gdyz zrozumiała, jak bardzo pilnie potrzebne jest pojednanie między chrześcijanami. Gdy wybuchła II wojna światowa, Brat Roger, pamiętajac o tym ważnym kroku swojej babci, poszedt za jej przyktadem. Opuścit Szwajcarię, w której urodzit się i wychowat, wyjechat do Francji, gdzie trwała wojna, 
i osiedlit się w pobliżu Cluny. Pragnat tam podjać życie inspirowane Ewangeliq i zatożyć wspólnotę, która miataby charakter monastyczny. Miała ona ponadto żyć blisko ludzi potrzebujących, najuboższych. Przez pierwsze dwa lata Brat Roger mieszkat w Taizé zupetnie sam, nie dysponowat też dużymi środkami, by pomagać ludziom potrzebujacym, ale ponieważ Taizé znajdowało się na linii frontu, dlatego dawat w swoim domu schronienie uciekinierom wojennym i następnie kierowat ich do Szwajcarii, gdyż granica ze Szwajcaria przebiegała niedaleko Taizé. Obecnie we Wspólnocie żyje ponad stu braci. Część z nich została wystana z Taizé i mieszka w matych wspólnotach, zwanych ,fraterniami", na innych kontynentach, w takich państwach, jak Brazylia, Bangladesz, Korea Poludniowa, Senegal i Kenia.

- Skąd wzięło się u Brata Rogera - człowieka wychowanego w tradycji protestanckiej - zainteresowanie monastycyzmem?

- Brat Roger studiowat ewangelicka teologie, a swoja teze teologiczna, czyli odpowiednik dzisiejszej pracy magisterskiej, pisat na temat monastycyzmu benedyktyńskiego. Widziatem okładkę tej pracy. Byt tam dopisek, że uniwersytet - Brat Roger studiowat w Lozannie i w Strasburgu - nie bierze odpowiedzialności za tezy zawarte w pracy. Profesorowie byli jednak na tyle uczciwi, że pracę, która była napisana poprawnie metodologicznie, uznali.

- Skoro formowanie się Wspólnoty w Taizé nie było początkowo w sposób wyraźny związane z ideą dialogu, a szczególnie dialogu młodych, to w jaki sposób w Taizé odkrywana była potrzeba dialogu i potrzeba skoncentrowania się na dialogu młodych?

- Spotkanie z młodymi i dialog z nimi to rzeczywiście dopiero późniejsze odkrycie - historia nieplanowana przez Wspólnotę i raczej nieoczekiwana. Młodzi zaczęli przyjeżdżać do Taizé dopiero po 10-15 latach istnienia Wspólnoty. Pierwsi bracia dołaczyli do Brata Rogera w 1944 roku w Genewie, gdzie Brat Roger schronit się w zwiazku z niebezpieczeństwem aresztowania przez Gestapo za prowadzonq działalność. Kiedy Taizé było już wyzwolone, Brat Roger wraz z pierwszymi wspótbraćmi powrócili na te tereny, aby prowadzić proste życie zakonne, monastyczne, obejmujqce modlitwe, prace, cisze i gościnność. Otwarcie na obcego, na przybysza byto zawsze ważne $w$ tradycji monastycznej $i$ Wspólnota $z$ Taizé pielegnowata ten element tradycji. W Regule znajduje się zdanie: „Gości mamy przyjać jak samego Chrystusa odwiedzajacego Wspólnote”. W ten sposób pierwsi młodzi ludzie odnaleźli Taizé, ponieważ po prostu znaleźli miejsce, gdzie ich ugoszczono, w którym ich stuchano, zainteresowano się nimi. Brat Roger umiat stuchać i posiadat dar zaufania ludziom. 
Pierwsze spotkania z młodymi byty organizowane z dala od domu braci ze względu na obawe, że gwar zwiqzany z ich przybyciem może zachwiać równowage życia monastycznego. Ośrodek dla młodych zbudowano zatem pare kilometrów od Taizé, w squsiedniej wiosce. Bracia do niego dojeżdzali, a młodzi od czasu do czasu przychodzili na modlitwe do kościółka romańskiego w Taizé, z którego korzystała Wspólnota. W Taizé nie było zreszta warunków do tego, żeby przyjać większe grupy, bo to maleńka wioska. Taki stan nie trwat jednak dtugo. Brat Roger, który zawsze mobilizowat braci do tego, aby pojednania szukać coraz energiczniej, nie wpadajac $w$ rutyne, szybko zorientowat się, że młodzi będa raczej sprzymierzeńcami niz przeszkoda $w$ wypetnianiu powołania Wspólnoty. Zrozumiat, jak duży potencjat zawiera w sobie młodość, i bracia pomalutku zgodzili się na to, aby spotkania z młodymi odbywały u boku Wspólnoty, na naszym wzgórzu.

Wymagało to wielkich zmian w życiu Wspólnoty. One nie dokonaty się, oczywiście, gwaltownie, ale systematycznie trzeba byto dostosowywać monastyczny tryb życia do takiej sytuacji, że bardzo często, a potem, w miare upływu lat, właściwie stale na wzgórzu przebywali młodzi. Podstawowym miejscem spotkania z młodymi był w Taizé zawsze kościót. Dialog stawał się możliwy, ponieważ w Taizé było dużo ciszy i skupienia - ciszy, w której wstuchiwano się w słowo Boże, to pierwsze, najważniejsze słowo, które potrzebuje tej gleby, jaka jest skupienie, cisza, oderwanie od swoich myśli, spraw, zeby skierować się na tego drugiego. Trzeba stuchać, naprawdę stuchać. Myślę, że to byt w Taizé zawsze fundament rozmowy, dialogu i porozumienia. Wszyscy, zarówno młodzi, jak i bracia, najpierw trzy razy dziennie spotykali się na modlitwie, a dopiero potem na wymianie myśli i doświadczeń.

- Co skłania młodych ludzi do przybycia do Taizé? Jakie stawiają pytania i jakie wyrażają obawy oraz nadzieje odnośnie do otaczającej ich rzeczywistości?

- Motywy przybycia do Taizé zmieniaty się z uptywem czasu. Na poczatku, w latach 60., zaraz po Soborze Watykańskim II, była to troska o Kościół i szukanie swojego miejsca w tej nowej, posoborowej sytuacji Kościoła. Mówiło się przecież wówczas, że ludzie świeccy maja mieć dużo więcej do powiedzenia w Kościele. Brat Roger na zaproszenie Jana XXIII byt obserwatorem na wszystkich sesjach Soboru Watykańskiego II, dlatego też duch Soboru bardzo głęboko wnikat w życie Wspólnoty. Tak jak wspomniałem, Brat Roger miat zdolność stuchania, ale to stuchanie przekładało się na życie Wspólnoty. Biblia mówi, że ten stucha, kto naprawdę żyje tym, co styszy. Kiedy Brat Roger wracat z kolejnych sesji Soboru, to natychmiast to, co tam ustyszat, co odkryt przez przebywanie w sercu Kościoła, stawało się czqstkq życia $w$ Taizé. Zauważyłem to, kiedy przygotowywałem się do święceń ka- 
płańskich. Musiałem wówczas przeczytać Katechizm Kościoła katolickiego i podczas lektury stwierdziłem, że ja już to znam. Dla mnie to nie było nic nowego, to była część naszego życia w Taizé. W latach 60. nie bytem jeszcze we Wspólnocie, ale tak to sobie wyobrażam, ponieważ analogiczny proces obserwowatem, gdy Brat Roger wyjeżdzat w jakaś podróż, na przykład do Indii. Gdy wracat, a podczas podróży odkrył coś ważnego, co mogło wzbogacić Wspólnote, natychmiast stawało się to częścia jej życia.

W latach 70. na pierwszy plan wysunęty się kwestie spoleczne, a zwtaszcza temat sprawiedliwości w świecie. Po wydarzeniach 1968 roku młodzi przyjeżdzali do Taizé na fali buntu. Byty to trudne lata dla Taizé. Brat Roger opowiadał nam, że myślat o zamknięciu Taizé i przeniesieniu Wspólnoty gdzie indziej. Nie uczynit tego jednak, ponieważ cały czas modlitwa byta przez przyjeżḋajacych szanowana. W latach 70. bracia utrzymywali liczne kontakty z Amerykq Lacińska, Hiszpaniq, Portugaliq. Od lat 60. nawiazywali też kontakty z Europa Środkowq i Wschodniq, starajac się wtaczyć doświadczenie Kościoła w tym regionie w poszukiwania w Taizé. W latach 70. bracia przyjeżḋali więc do Polski, do NRD, do Czechostowacji, udawało się nawet pojechać do Rosji. Celem wyjazdów nie było przekazywanie czegokolwiek, nauczanie, ale stuchanie i uczenie się samemu doświadczenia Kościoła i chrześcijan w Europie Środkowej. Lata 70. to także czas moich pierwszych osobistych kontaktów z braćmi. W 1971 roku brat Clément, pod koniec swojego miesięcznego pobytu w Polsce, odwiedzit Poznań. Podczas spotkania $z$ nim uderzyło mnie, że on niczego nie mówi, niczego nie głosi, nie przekazuje żadnej doktryny - tylko stucha. Bracia chcieli po prostu zrozumieć. Jednym z warunków dialogu jest wtaśnie zaciekawienie tym drugim. Z pierwszego mojego kontaktu z Taizé zostało mi zatem przekonanie, że bracia stuchaja, chca się dowiedzieć. Kiedy potem wstapitem do Wspólnoty, bardzo dtugo wypytywali mnie o maryjność, bo to było coś, co ja wnositem tam jako Polak. Polska jest przecież krajem, w którym żywy jest kult maryjny. Wypytywali mnie więc na przyktad, co to znaczy, że Maryja jest Królowa Polski.

- Skoro w wypowiedzi Brata pojawił się wątek osobisty, to odchodząc na moment od głównego tematu, chcielibyśmy zapytać, co Brata skłoniło, żeby wstapić do Wspólnoty? Co sprawiło, że akurat w tym kierunku Brat skierował kroki, a nie na przykład do seminarium metropolitalnego?

- Zetknatem się z Taizé pod koniec lat 60. i na poczatku lat 70. W 1967 roku rozpoczałem w Poznaniu studia ekonomiczne. Byt to czas dużej aktywności duszpasterstw akademickich. Jako młodzi chrześcijanie znajdowaliśmy w nich przestrzeń wolności, dialogu, rozmowy o tym, co przecież najważniejsze. Gdzie indziej trudno było prowadzić takie rozmowy. Ja uczestniczylem $w$ duszpasterstwie organizowanym przez księży zmartwychwstańców. 
W tamtych latach w Polsce istniało żywe zainteresowanie ekumenizmem. Po Soborze w seminariach organizowano koła ekumeniczne, w duszpasterstwach istniały grupy ekumeniczne, które utrzymywały kontakty między chrześcijanami różnych wyznań. Poznań stwarzał duże możliwości $w$ tym względzie. Byty tutaj wspólnoty: luterańska, baptystów, metodystów. Kontakty z nimi byty bardzo otwarte $i$ wtedy petne nadziei na szybkie zjednoczenie.

Biorac $w$ tym wszystkim udziat, natknałem się na trop Taizé, na pierwsze informacje o Wspólnocie. W 1968 roku ukazała się w Polsce ksiażeczka, opisujaca życie braci i zawierajaca regułe Brata Rogera. Poruszyła nas ona do tego stopnia, ż jako studenci próbowaliśmy nawet jakoś wedtug niej żyć. Reguła była bardzo otwarta, podkreślała radość bycia chrześcijaninem $i$ wskazywała na radykalizm, który nie byt oparty na jakichś wyczynach pobożnościowych - jeśli tak można powiedzieć - ale na samym Chrystusie. Brat Roger podkreślat, że sam Chrystus radykalnie angażuje się $w$ życie człowieka, który mu na to pozwala. Ten radykalizm bardzo nam odpowiadat, a szczególnie mnie osobiście.

Bardzo ważne byty też dla mnie kontakty z podwarszawskimi Laskami. $W$ tym ośrodku prowadziła wówczas rekolekcje ekumeniczne s. Joanna Lossow, pionierka polskiego ekumenizmu. Odbywaty się one dwa razy w roku. Wyjazdy z Poznania do Lasek umożliwiaty nam nawiazywanie kontaktów z osobami z catej Polski. Między innymi też przez to nieżyjacy już brat Clément odwiedził Poznań. Dowiedziat się $w$ Warszawie, że $w$ Poznaniu jest grupa młodych ludzi, którzy dobrze znaja nawet regułe Wspólnoty.

Potem utrzymywałem ten kontakt z Taizé, dzięki czemu mogłem wyjechać do Taizé, mimo że to wtedy było bardzo trudne. Zostałem zaproszony przez Wspólnotę. Pierwszy raz pojechałem w 1972 roku, w 1975 roku podjęta została decyzja o wstapieniu do Wspólnoty - wtedy pojechatem, żeby prosić o przyjęcie, $i$ w 1977 roku wstapitem do Wspólnoty. Takie byty poczatki.

- Jak to się stało, że przyjął Brat święcenia kapłańskie?

- Wstapiłem do Wspólnoty jako świecki człowiek i dopiero później zostałem poproszony przez Brata Rogera o przyjęcie święceń kapłańskich. Miało to miejsce dopiero 10 lat temu, a we Wspólnocie jestem już 30 lat.

- Wracając do pytania o motywy przyjazdu młodych do Taizé - z jakimi problemami, pytaniami przyjeżdża dzisiejsza młodzież?

- Zainteresowanie Kościołem czy problemami społecznymi troche zanikło wśród młodych ludzi. Był taki czas, że trzeba było mobilizować ich do myślenia o takich sprawach. Zaczęli natomiast interesować się duchowościa. Wprowadziliśmy zatem do programu spotkania, które można nazwać katechetycznymi. Bracia codziennie wychodza do młodych, organizuja ich 
w grupy i proponuja różne tematy. Od dluższego czasu sq to przede wszystkim katechezy biblijne. Bardzo chętnie $i$ uważnie ich stuchaja. Katechezy biblijne staja się z kolei impulsem do rozmowy w grupach. Taki sposób organizowania spotkań ustalit się i trwa od dwudziestu paru lat - najpierw spotkanie z braćmi, stuchanie, a nastęnie rozwijanie tematu w matych grupach. Brat Roger zaczą równiez pisać do mtodych listy, w których proponuje kilka myśli dotyczqcych wiary, pojednania, zaangażowania chrześcijańskiego. Jest to baza do codziennych spotkań w Taizé i poza Taizé.

- Co młodzi mówią na temat własnego życia, jakie wyrażają obawy i troski, dotyczące ich przyszłości?

- Młodzi ludzie przyjeżdżaja do Taizé z calym bagażem swoich osobistych doświadczeń. To $w$ zasadzie jest najważniejsze w Taizé, najbardziej konkretne: ich bardzo osobiste pytania i bardzo osobiste doświadczenia życiowe, które nieraz sq trudne i skomplikowane. Bardzo wiele czasu poświęcamy zatem na osobiste kierownictwo - tak byśmy to w tradycyjnym języku nazwali - a my mówimy o stuchaniu, o towarzyszeniu duchowym. Codziennie, po wieczornej modlitwie bracia zostaja w kościele $i$, kiedy jeszcze trwa śpiew, modlitwa, ci młodzi moga do nas przyjść i rozmawiać. Sa wśród nas również kapłani, którzy udzielaja sakramentu pojednania. W Taizé jest też możliwość przeżycia tygodnia $w$ ciszy, $w$ milczeniu, połaczonego z codziennym spotkaniem z jednym z braci na rozmowe duchowa. Dialog, duchowy dialog, który dotyka bardzo osobistych doświadczeń, jest dzisiaj młodym niezwykle potrzebny. Z naszego małego wzgórza widzimy, jak mało maja młodzi ludzie możliwości rozmowy o sprawach ważnych, dla nich fundamentalnych. Żyja nieraz w bardzo dobrych rodzinach, w których jednak nie ma rozmowy. Nierzadko maja 17-18 lat i rozmawiaja z dorostym dopiero po raz pierwszy o swoich osobistych doświadczeniach.

- Jakie miejsce w rozmowach w Taizé zajmuje pytanie o człowieka, o to, kim jest człowiek?

- Rozmowy o czlowieku toczq się w oparciu o Pismo Święte. Nie zadajemy pytań w sposób filozoficzny. Odpowiedź na pytanie, kim jest człowiek, poszukiwana jest zatem w oparciu o różne fragmenty Ksiag Biblijnych. Nie tak dawno zorganizowaliśmy na przykład tygodniowe studium pierwszych rozdziałów Księgi Rodzaju. Pytanie, kim jest czlowiek, jest tam obecne, jest to nawet temat główny. Rozważania biblijne maja ponadto zawsze wydźwięk egzystencjalny. Jest to konsekwencja faktu, że mtodzi przyjeżdzaja od Taizé z pytaniem o sens życia, sens ludzkiego życia w ogóle i sens ich konkretnej egzystencji. Owo pytanie musi się zatem znaleźć w centrum doświadczenia spotkania w Taizé. Na owo pytanie nie udzielamy jednak gotowych odpowie- 
dzi. Unikamy podawania recept, gotowych formułek. Wiemy, co mówi Pismo Święte, pomagamy zrozumieć głębię stowa Bożego i mamy zaufanie, że oni potem sami znajda odpowiedzi na nurtujace ich pytania.

- Skoro wywołany został temat sensu ludzkiego życia, to aż trudno nie zapytać, jak młodzi ludzie, przybywający do Taizé, rozumieją sens życia i czy pojawiają się u nich postawy, świadczące o trudnościach w odnajdywaniu sensu życia?

- Bardzo trudno generalizować w tej kwestii. Do Taizé przyjeżḋa różna młodziez. Wielu jest takich, którzy dzięki rodzinie, wychowaniu, przyjaciołom nie maja trudności z odpowiedziq na pytanie o wiarę, sens swojego życia i sens ludzkiego życia w ogóle. Po niektórych widać również, że przeszli formację w parafiach czy duszpasterstwach. Sa to na przykład w większości młodzi ludzie z Polski. Dla nich pytanie o sens życia nie jest najważniejsze. Jest też bardzo wielu zagubionych młodych ludzi, którzy przyjeżdzaja do Taizé i po raz pierwszy stykaja się z modlitwa oraz z pytaniami o sens życia. Wiadomo, ze dla nich sq to pytania fundamentalne.

Myśle, że w Taizé młodzi pomagaja sobie wzajemnie w odnajdywaniu odpowiedzi na pytanie o sens życia. Dokonuje się to poza spotkaniami z braćmi, wprowadzeniami biblijnymi czy katechezami. W Taizé jest dużo czasu na spotkanie i rozmowe z drugim człowiekiem. Grupy sq zawsze międzynarodowe, zawsze próbujemy je tak wymieszać, żeby była szansa, że w każdej grupie będa osoby, które maja coś do powiedzenia, czyli maja jakieś dobre doświadczenie życiowe, które będa mogli przekazać tym, którzy takiego doświadczenia nie mieli szczęścia mieć. Jest wiele takich spotkań, które maja miejsce $w$ Taizé i które pomagaja młodym zmierzyć się z pytaniem o sens życia, a których teraz nie da się po prostu opisać.

- Z jakich krajów przyjeżdżają te osoby, dla których pytanie o sens życia jest pytaniem fundamentalnym?

- Dzisiaj trudno już jednoznacznie odpowiedzieć na to pytanie. Powiedziałem wcześniej, że przyjeż̇̇ajacy z Polski sq raczej osobami z pewna religijna formacja, ale obecnie $w$ tych grupach sa takie tacy ludzie, którzy ustyszeli o jakimś pozytywnym doświadczeniu od swoich kolegów, i dla nich samych pytanie o sens życia jest pytaniem fundamentalnym. Nie uogólniajac, można jednak zaryzykować stwierdzenie, że wśród Szwedów, Holendrów czy Niemców wielu jest takich, którzy przyjeżdzaja do Taizé z pragnieniem znalezienia sensu swojego życia.

Kiedy jeszcze Brat Roger żyt, można było zobaczyć w Taizé bardzo wzruszajacy widok. Byt już w podeszłym wieku, nie mógt za bardzo rozmawiać, nie za dobrze też styszat, ale - tak jak to robit przez całe życie - zostawat 
zawsze w Kościele po wieczornych modlitwach, siadat gdzieś na krzesetku $z$ gotowościq wystuchania tych, którzy tego potrzebowali. Gdy w Taizé byli na przykład Szwedzi, to oni w kolejce się ustawiali, aby podejść do Brata Rogera. A on na nich patrzyt. Można było dostrzec, że oni podchodzili po to, żeby wreszcie ktoś na nich popatrzyt i to tak popatrzyt, żeby oni zrozumieli, że ich dostrzega i ceni. Brat Roger patrzył na nich spojrzeniem, o którym często młodzi mówili, że byto bardzo głębokie. Myśle, że wielu młodych z krajów zachodnich przyjeżdza nadal do Taizé z takim pragnieniem, z takim oczekiwaniem. Albo to pragnienie dopiero się w nich budzi, kiedy sq na modlitwie po raz pierwszy w życiu $i$ w czasie ciszy zaczynaja stuchać swojego serca.

- Powiedział Brat, że fundamentem dialogu w Taizé jest Objawienie; że w Taizé nie toczy się dyskusji na tematy społeczne, ale buduje przestrzeń do dialogu, opartego o słowa Chrystusa. Czy młodzi ludzie otwierają się na to słowo, czy po prostu akceptują tę konwencję?

- Do Taizé przyjeżdżaja też tacy ludzie, którzy nie sa przygotowani na przyjęcie słowa Bożego, ale ponieważ sq tam też inni, choćby my, bracia, którzy tym stowem żyjemy na co dzień - nie jesteśmy mistrzami, ale przynajmniej próbujemy; sq tam również młodzi ludzie, którzy posiadaja jakieś doświadczenie wiary; to wciaga tych, którzy właśnie nie sa przygotowani. Dzięki temu w Taizé można zaobserwować niezwykta moc Stowa, które, jeśli pada na ludzkie serce otwarte w minimalnym stopniu choćby poprzez fakt samej obecności na modlitwie, przynosi owoce, i to bardzo często zupetnie niespodziewane. Nawet jeśli ktoś zupetnie nie potrafi się modlić, to $w$ atmosferze ciszy, jeżeli daje pierwszeństwo Stowu i dziataniu Ducha Świętego, który to Stowo zasadza w ludzkim sercu, może się w jego wnętrzu bardzo wiele wydarzyć. Jeden brat z naszej Wspólnoty jest właśnie takim młodym czlowiekiem, który kiedyś został zaskoczony kompletnie działaniem Ducha Świętego w jego sercu. To nie sq nadzwyczajne, spektakularne doświadczenia, to wszystko odbywa się w ciszy, dyskretnie, w pewnej surowości. Brat Roger był zawsze takim człowiekiem, który nie prowadzit do spektakularnych doświadczeń. Mówi się często o emocjonalnym charakterze przeżyć w Taizé, a ja myślę, że jeżeli ktoś dobrze zna Taizé, to wie, że owe przeżycia sa bardziej surowe niz emocjonalne.

- Jakie cechy, wewnętrzne postawy, niezbędne są do prowadzenia dialogu, który ma miejsce w Taizé? Czy młodzi ludzie, dojrzewający we współczesnej kulturze, która nie jest kulturą refleksji, tylko kulturą obrazu, są zdolni do dialogu, czy raczej ten dialog jest $\mathrm{w}$ ich przypadku utrudniony?

- Człowiek jest stworzony do dialogu, więc jest również do niego zdolny. Ta zdolność nie może $w$ nim ulec kompletnemu zniszczeniu, może być 
tylko przyttumiona lub niewyćwiczona, jeżeli nigdy nie byt w takiej sytuacji, ze stucha, otwiera się, wychodzi naprzeciw drugiemu, tylko zawsze musiat walczyć, żeby być skutecznym i narzucić swoje stanowisko. Wtedy nie ma umiejętności dialogu $w$ tym sensie, że nie jest ona wyćwiczona. Nieraz wystarczy niewiele, żeby młody człowiek zrozumiat, odkrył, jaka radość płynie $z$ otwarcia się na drugiego człowieka. Taka radość obserwujemy w Taizé, kiedy ludzie zasępieni na poczatku tygodnia, po tygodniu zdaja się być radośni, otwarci, gotowi do refleksji i do stuchania drugiego człowieka. Myśle więc, że taka zdolność jest w człowieku i nie można jej zniszczyć. Kiedy widzi się, jak owa zdolność budzi się, wtedy zawsze pojawia się wiara w drugiego człowieka, wiara w to, że Pan Bóg dobrze go stworzyt, że się nie pomylit.

Bardzo fundamentalnym warunkiem dialogu jest umiejętność stuchania. Dzisiaj brakuje nam tej umiejętności. Chcemy raczej nadawać, wyrażać się, aby zaistnieć. Tymczasem dialog wymaga pewnej pokory i uznania, że nie jestem mistrzem, że wszystkiego nie wiem, że mogę się czegoś od drugiego nauczyć.

Warunkiem dialogu jest również wolność. W Taizé młodzi ludzie odkrywaja sens wolności. Bardzo często mówia, że tu ich nikt do niczego nie zmusza, ale gdy dzwony bija, oni ida do Kościoła. Nie ma takich, którzy nie ida. Podkreślaja równocześnie, że nie sq do tego zmuszani. Poczucie wolności otwiera człowieka na rozmowe z drugim. Jeżeli mam wolność, to znaczy, że nikt mna nie manipuluje. Dialog jest trudny, kiedy mam poczucie, że ktoś może mna manipulować, wykorzystać moje stowa przeciwko mnie, do jakiś swoich interesów. A wolność jest możliwa, kiedy opieramy się na Ewangelii, na Panu Bogu, bo On dat nam wolność.

- Współcześni młodzi ludzie są zainteresowani robieniem kariery: zawodowej, społecznej, politycznej. Czynią wiele, aby wzmocnić kompetencje i możliwości życiowego startu. Co Bracia czynią, aby tych młodych ludzi otworzyć na wartości wyższe, na sens życia?

- Jest to prawda, że młodzi ludzie zajmuja się obecnie sprawami codziennymi, praktycznymi, zdobywaniem wiedzy, ale przy tym takim jej gromadzeniem, które nie daje możliwości wykorzystania jej w stużbie drugiemu.

Staramy się w Taizé otwierać młodych ludzi na dobra duchowe, ale robimy to $w$ dosyć specyficzny sposób. Zauważyliśmy na przykład, jaka wartościa jest wspólna praca. W Taizé młodzi musza sami robić praktycznie wszystko, co jest zwiqzane z organizacja wspólnego życia dla nieraz 5-6 tysięcy ludzi, którzy spędzaja tam razem tydzień. Muszq sprzatać, zamiatać, gotować, wydawać pożywienie, przyjać siebie nawzajem. Wzajemna stużba otwiera człowieka na wymianę, na refleksję. W życiu codziennym oni sq wyręczani przez rodziców czy zawodowe służby. Gdy taki chłopak dostanie u nas traktor i ma 
nim jeździć, stwierdza, że coś potrafi i zaczyna doceniać pracę jako sposób nie na robienie pieniędzy, ale na stużbę innemu człowiekowi. To z kolei otwiera na innego człowieka. Gdy powierzamy mu robienie śniadania i ma w zwiqzku z tym wyprodukować codziennie przez caly tydzień 5 hektolitrów herbaty, jest to dla niego niesamowite.

Rozmawiamy tutaj o dialogu i jego warunkach, majqc na myśli dialog teoretyczny. On jest oczywiście możliwy, ale w Taizé dialog toczy się przez doświadczenie życia, doświadczenie egzystencjalne. Codzienne sprawy życia mogq również wspierać dialog między ludźmi, jeżeli sq one wykonywane w sensowny sposób. Młodzi ludzie odkrywaja to w Taizé. Mówia, że ta codzienna praca ma sens.

- Jakie trudności związane są z dialogiem młodych, wychowanych w różnych kulturach i tradycjach?

- Na pewno taka trudnościq, która trzeba pokonać na poczatku, jest język. Druga trudność zwiqzana jest z różnicq mentalności, różnicq w podejściach do życia, jakq obserwuje się szczególnie między młodymi ze Wschodu $i$ Zachodu. Polega ona na tym, że podejście do życia na Zachodzie jest bardzo pragmatyczne i uporzadkowane - tam, gdy podejmuje sie jakieś działanie, trzeba najpierw zaplanować kolejne etapy realizacji celu, dopiero wtedy kompletuje się wszystko, co potrzeba, i rozpoczyna pracę. W mentalności wschodniej jest inaczej - gdy znamy cel, ruszamy w droge, $w$ międzyczasie zdobywajac elementy potrzebne do pokonania kolejnych trudności.

Moje doświadczenie życia z braćmi z Zachodu - bytem pierwszy ze Wschodu, to dla nich też musiato być trudne - podpowiada mi, że warto uszanować te dwa podejścia do życia, gdyż można wtedy bardzo wiele razem zrobić. Pracowałem kiedyś dużo z jednym z braci z Anglii. Gdy jakiś element wypadt z jego schematu zmierzania do celu, rezygnowat z pracy, stwierdzajac, że nie da się jej ukończyć. W życiu nie da się jednak wszystkiego zaplanować i nie oznacza to konieczności rezygnacji z dqżenia do celu. Nasza wschodnia mentalność, która nigdy nie powie, że już się nie da czegoś zrobić, pobudzała mnie do szukania alternatywnych rozwiazań, co bardzo często przynosiło pozytywny skutek. Z biegiem czasu i podczas wspólnej pracy nauczyliśmy się liczyć jeden na drugiego: ja liczytem, że mój wspótbrat dobrze wszystko zaplanuje, a on na mnie, kiedy pojawiaty się niespodziewane przeszkody. W ten sposób wiele razem zrobiliśmy.

Bardzo znaczqca jest różnica mentalności między Europejczykami a Afrykańczykami. Ci ostatni maja na przykład kompletnie inne niż nasze poczucie czasu. Wnoszq też w nasze spotkania wiele spontaniczności, radości. $W$ Taizé jest miejsce na doświadczenie tych wszystkich trudności, odmien- 
ności, co mobilizuje do twórczego przezwyciężania ich. Zapraszamy więc młodych ludzi z innych kontynentów do uczestnictwa w spotkaniach.

- W jaki sposób pobyt w Taizé przekłada się na późniejsze funkcjonowanie we wspólnocie parafialnej, w Kościele lokalnym?

- To było zawsze wielkim problemem, od kiedy młodzi zaczęli przyjeżdżać do Taizé, co zrobić z tym tygodniowym doświadczeniem, które dla nich - mieliśmy tego świadomość - jest mocne, jest nieraz przebudzeniem, można powiedzieć, że nawet wstrzqsem; Brat Roger mówit, że jest to „, szok, uderzenie sensem". Brat Roger wyrażat jednak od poczatku przekonanie, że nie możemy młodych wiazać z Taizé, ze soba, ze Wspólnota, z tym wzgórzem, że nie możemy tworzyć żadnego ruchu, żadnych struktur, żadnej organizacji. Towarzyszyła nam zatem świadomość, że doświadczenie Taizé może być jedynie prowizoryczne i inspirujace, ale młodych trzeba zachęcić do tego, zeby wracali do własnych środowisk, do własnych wspólnot lokalnych i kościelnych. Tak też czynimy od 30 lat. Poczatkowo byty jeszcze próby tworzenia małych grupek, odwołujacych się do Taizé, czy powołania tak zwanego Soboru Młodych, ale szybko tego zaniechano ze względu na zbytnie skoncentrowanie na Taizé.

Po pewnym czasie zrodziła się myśl, aby wysłać młodych w pielgrzymke zaufania przez ziemie. Niewatpliwie inspirujace byty dla tej idei kontakty z Polska, która jest znana jako kraj pielgrzymujacy. Na pielgrzymki z Warszawy do Częstochowy bracia wysyłali młodych już w końcu lat 60. Wędrowali, wmieszani w tłum. Pielgrzymka zaufania przez ziemię skierowana jest nie do Taizé, ale od Taizé. Ważnymi dla niej etapami staty się Europejskie Spotkania Młodych, organizowane od ponad 30 lat.

Owa pielgrzymka ma ponadto pomóc młodym w powrocie do własnych parafii po tygodniu mocnego doświadczenia w Taizé. Jest to trudne, gdyz $w$ wielu parafiach często nic albo niewiele się dzieje, patrzac z perspektywy młodego człowieka. Jest oferta dla ludzi bardziej dojrzałych, ale młody człowiek nie spotyka tam swoich rówieśników. Przynagleni zatem niejako przez młodych zostawiamy Taizé na kilka miesięcy (ja w Poznaniu jestem już czwarty miesiac), zostawiamy wygode i komfort duchowy, i towarzyszymy młodym wich miejscach zamieszkania. Nie jest to proste.

- Jak w praktyce wygląda powrót młodych do parafii, co o nim mówią ludzie młodzi, z którymi mają Bracia kontakt, jakie konkretne owoce przynosi pobyt w Taizé?

- Nic nie jest idealne w życiu. To nie jest tak, że po tygodniu w Taizé wszyscy wracaja do parafii i stajq się najaktywniejszymi jej członkami. To zależy od temperamentu ludzi, od ich możliwości, od tego, jak zostana po 
powrocie z Taizé przyjęci. Jeżeli ktoś wraca do parafii, a jej członkowie nie potrafia nawiqzać dialogu, nie chca zrozumieć, co się wydarzyto w sercach tych młodych ludzi - myślę też między innymi o duszpasterzach - to wiadomo, że doświadczenie pobytu w Taizé obumiera. Ale tam, gdzie młodzi po powrocie trafiaja na dobry grunt, to znaczy na zainteresowanie, na życzliwe wsparcie duszpasterzy, istnieje szansa, że doświadczenie modlitwy, wiary, poszukiwania, oraz tego, co przeżyli w Taizé, zostanie przeniesione $w$ życie parafialne i wyda piękne owoce. Obserwowaliśmy to w Poznaniu. Tegoroczne spotkanie młodych odbyto się wtaśnie w tym mieście, ponieważ wiedzieliśmy, że w wielu parafiach Poznania młodzi ludzie wracajacy z Taizé potrafili zawiqzać grupy modlitewne, pogłębiania wiary i stużqce innym. Sa to grupki życia chrześcijańskiego, które próbuja żyć ewangelia w sposób konkretny $i$ integralny. Niewatpliwie dzieje się tak, ponieważ oni spotkali się z życzliwościq i arcybiskupa, i duszpasterzy.

Leży nam w Taizé na sercu komunijny wymiar Kościoła. Mówit o nim papież Jan Pawet II, jako o jednym z trzech priorytetów dla chrześcijan. Mówił o tym w bardzo dynamiczny sposób, że Kościót powinien być bardziej kontemplacyjny, bardziej komunijny, wspólnotowy, i bardziej misyjny. Te trzy priorytety można znaleźć w jego dokumentach z drugiej części pontyfikatu, $w$ dokumentach zwiqzanych $z$ obchodami milenium. W Poznaniu widzieliśmy, że komunia, wspólnota, zaufanie wydaja owoce.

Mamy świadomość, że trwate zmiany dokonuja się powoli, powoli dojrzewaja. Owoce nie pojawiaja się od razu. My pragniemy coś zasiać, ale wzrost nie od nas zależy. Oczywiście, człowiek cieszy się, gdy może zobaczyć owoce swojej pracy, swojego zaangażowania, ale pracujac nie można ich oczekiwać.

Miłym znakiem trwałości doświadczenia Taizé sq dla nas młode rodziny. Przygotowany przez nas program dla rodzin z dziećmi cieszy się tak wielkim powodzeniem, że musieliśmy wprowadzić limity przyjęć dla poszczególnych krajów. Nie byliśmy w stanie wszystkich przyjać. Osoby, które zgłaszaja się do uczestnictwa w tym programie, to $w$ większości ludzie, którzy bywali już kiedyś w Taizé, przerwali kontakt na około 10 lat, a teraz wracaja ze swoimi dziećmi. Sa w wieku trzydziestu kilku lat, a ich dzieci sa już kilkuletnie. Skoro wracaja, to znaczy, że doświadczenie, które miato miejsce w Taizé, byto i jest ważne wich życiu.

Mówiqu o owocach, należatoby również wspomnieć, że dla wielu mtodych pobyt $w$ Taizé jest czasem odkrywania powolania. Radościq dla nas jest to, że młodzi ludzie w Taizé odkrywaja swoje powolanie do życia kaptańskiego, do życia zakonnego, protestanci do życia poświęconego Bogu jako pastorzy. Mamy sygnaty, że w wielu seminariach na przyktad w Niemczech sq ludzie młodzi z doświadczeniem pobytu w Taizé. Kiedyś rektor jednego 
z seminariów powiedziat, że połowa kandydatów do jego seminarium to osoby, które były w Taizé i tam odkrywaty i umacniaty swoje powołanie.

- Jakie znaczenie dla współczesnego młodego człowieka posiada pytanie o Boga? Jaki kształt przybiera to pytanie dzisiaj?

- Młodzi ludzie przyjeżdzaja do Taizé z wieloma watpliwościami co do istnienia Boga. Bardzo często mówiq o sobie, że po prostu nie wierza w Boga. Ale trzeba do tych deklaracji podchodzić ostrożnie, bo watpliwości nie oznaczaja jeszcze niewiary. Watpliwości sq motorem poszukiwania. Myślę więc, że do wyrazanych przez nich watpliwości należy właśnie podejść jako do świadectwa ich poszukiwań. Z pytaniem o Boga, o jego istnienie, o to, jaki jest, przyjeżḋa do Taizé bardzo wielu młodych ludzi.

Owe pytania przybieraja różna postać. Bardzo często sa to pytania wyrażane poprzez pytanie o cierpienie, bo przecież cierpienia nie brakuje $w \dot{z} y$ ciu, szczególnie w sytuacjach rodzinnych, tak bardzo skomplikowanych dzisiaj w wielu krajach. Podczas Europejskiego Spotkania Młodych w Poznaniu proponowaliśmy popołudniami rozważania tematyczne. Największym zainteresowaniem cieszyt się temat o Hiobie. Do parafi, w której jeden z braci prowadzit refleksje na temat Księi Hioba, przychodzity takie nieprzebrane ttumy, że trzeba było kolejne sale otwierać, aby ich pomieścić.

Duża popularnościq cieszyło się też zagadnienie wiary Abrahama, na temat której refleksje prowadzili ks. abp Stanisław Gadecki i naczelny rabin Warszawy, Michael Szudrich. Tam też byty nieprzebrane thumy.

Młodzi pytaja o Boga bardzo natarczywie i bardzo intensywnie szukaja odpowiedzi. Nawet jeżeli dla kogoś po przyjeździe do Taizé liczy się bardziej spotkanie z drugim człowiekiem, to jednak modlitwa, w której uczestniczy, sprawia, że pytanie o Boga też się w końcu pojawia. Myślę więc, że u niejednego człowieka Taizé wyzwala takie pytanie. W konsekwencji zdarzaja się w Taizé autentyczne nawrócenia.

- Dialog o Bogu nie oznacza jeszcze dialogu z Bogiem. Czy w Taizé, w miejscu spotkania tysięcy ludzi młodych, radosnych, pełnych życia, ludzie ci szukają dialogu z Bogiem?

- Tu również trudno generalizować. Nasza nadzieja i oczekiwaniem jest to, że oni spotkaja w końcu Chrystusa. Staramy się tworzyć miejsce, przestrzeń spotkania z Osoba Chrystusa. Świadectwem, że do takiego spotkania dochodzi w Taizé u niejednego z nich, choć na pewno nie u wszystkich, jest to, że osoby, które wracaja do Taizé, mówiq bardzo często, że czuja się w tym miejscu, jak u siebie $w$ domu i wracaja tutaj jak do domu. To jest niesamowite, bo kto byt $w$ Taizé, wie, że tam nic nie przypomina domu, w którym jest komfort, luksus, ciepło i mama wszystko zrobi. W Taizé wszystko trze- 
ba samemu zrobić, jest tak zgrzebnie, a oni mówiq, że czuja się tam, jak $w$ domu. Myśle zatem, że to w świqutyni odkrywaja prawde, że nie sq sami, że nie sa fundamentalnie sami, ale Ktoś jest w ich życiu, Ktoś, kto daje bezpieczeństwo. Staramy się więc tworzyć przestrzeń do spotkania z Chrystusem i mamy nadzieję, że do tego spotkania w ich życiu kiedyś dojdzie.

- Wróćmy do idei zjednoczenia chrześcijan. Czy Wspólnota jest wierna tej idei Brata Rogera i w jaki sposób stara się ją realizować?

- Mamy głęboka świadomość, że zjednoczenie chrześcijan jest powołaniem naszej Wspólnoty i temu powołaniu staramy się być wierni. Można to zobaczyć na przykładzie listów, które pisze obecnie Brat Alois. Zawsze jest w nich wyrażana troska o jedność, o pilne zjednoczenie chrześcijan. Od tego zależy wiarygodność chrześcijaństwa, szczególnie dziś, $w$ dobie globalizacji, w czasie, gdy technika umożliwia przekazywanie wiadomości na szeroka skalę. Bracia nasi żyja w krajach, gdzie chrześcijaństwo bardzo szybko się rozwija, na przykład w Korei Poludniowej. Mamy bliskie kontakty $z$ Chinami. Ostatnio Brat Alois napisat list $z$ Chin, byt tam prawie miesiac. To w tych krajach szczególnie mocno widać, jak bardzo potrzebne jest świadectwo jedności chrześcijan. Poza tym doświadczenie naszej Wspólnoty jest doświadczeniem codziennego pojednania, bo we Wspólnocie sq i katolicy, $i$ bracia pochodzacy z różnych protestanckich kościołów, więc my każdy dzień przeżywamy w pojednaniu.

- Jakie ważne, pozytywne wydarzenia miały miejsce, zdaniem Wspólnoty, w XX wieku na drodze do jedności chrześcijan, a jakie przeszkody okazały się nie do przejścia? Jaką drogą ku jedności kroczy obecnie Wspólnota $\mathrm{z}$ Taizé?

- W ostatnich latach obserwuje sie jakby spowolnienie procesu zbli$\dot{z} a n i a$ się do siebie chrześcijan. Niewatpliwie zbliżenie nastapiło $i$ dostrzegamy to doskonale w Taizé. Doceniamy wagę dokumentów ekumenicznych, tych najwazniejszych prac komisji dwustronnych $i$ wielostronnych, a także i Światowej Rady Kościołów. W Taizé interesowało nas jednak zawsze pojednanie i jedność widzialna Kościoła, a nie tylko uprawianie ekumenizmu. Doświadczeniem obecnego czasu jest to, że nie widać dobrze, w jakim kierunku miatby postępować proces zjednoczenia. Paralelne, blisko siebie, ale ciagle paralelne, drogi nie moga doprowadzić do jedności. A będziemy wędrować paralelnymi drogami, jeżeli będziemy się trzymać swoich ściśle wyznaczonych ścieżek, odwolując się często do swojej tożsamości, obrony tej tożsamości, której nie chcemy zatracić. W Taizé można dostrzec pewien rodzaj niecierpliwości jeżeli chodzi o zjednoczenie, bo, jak wspomniatem, pojednanie między chrześcijanami jest pilnie potrzebne. 
- Skoro do Taizé przyjeżdżają młodzi ludzie, bardzo często nie tyle wierzący, co poszukujący Boga, to czy oni w ogóle dostrzegają różnice między wyznaniami?

- Jest to bardziej problem Kościołów instytucjonalnych i ludzi dorostych. Młodzi faktycznie już bardzo często tych różnic nie dostrzegaja i one dla nich nie odgrywaja takiej ważnej roli. Często nie posiadaja po prostu odpowiedniej wiedzy, żeby widzieć różnice między wyznaniami. Może to trochę pomoże w zjednoczeniu?

- Jaką rolę w dialogu ekumenicznym odgrywa powrót do przeszłości? Czy w drodze do pojednania należy wracać do momentów trudnych i ran, skoro młodzi ludzie nie mają świadomości tych wydarzeń, czy może lepiej o nich zapomnieć i zastanawiać się nad wspólną przyszłością?

- Zastanawialiśmy sie podczas naszego poznańskiego spotkania, co dalej z pojednaniem. Jeden z prowadzacych dyskusje powiedziat, że rany, konflikty nie sq problemem ludzi mlodych, którzy żyja już w sytuacji pokoju. Młodzi ludzie nie doświadczyli już tych ran bezpośrednio, ale o historii zapomnieć nie można. Oni też znajq historię i często ze swojej tradycji przejęli różne uprzedzenia, stereotypy, więc nie można nie wracać do historii. Nie można zaprzestać pracy nad pojednaniem, bo bardzo łatwo i szybko można ześlizgnać się w stereotypy i uprzedzenia, $i$ wtedy wystarczy maleńki konflikt, żeby cofnać się w pojednaniu o dziesiatki lat.

- Czy wśród Braci nie pojawiają się niekiedy obawy, że w sytuacji pluralizmu religijnego i wyznaniowego wśród młodych przybywających do Taizé nie zatracą oni własnej tożsamości religijnej i wyznaniowej? Czy Taizé nie przyczynia się do budowania tak popularnej obecnie mentalności New Age?

- Ważne jest ukazanie Chrystusa. Jeżeli będziemy się mocno trzymać Osoby Chrystusa $i$ Ewangelii, wtedy nie będzie tego niebezpieczeństwa. Chrystusa, ale i Kościoła. Brat Alois podkreślit to w Poznaniu: Polacy poznajq Chrystusa w Kościele. Przywiqzani sq do tradycji, która jest zwiqzana z Kościołem, i tego musimy się od nich uczyć. W Taizé staramy się nieustannie ukazać młodym ludziom role, znaczenie Kościoła jako wspólnoty, w której żyje Chrystus. Ale też Osobę Chrystusa i znaczenie osobistej więzi z Nim.

Myślę, że ostatni Papieże też zwracali na to uwagę. Benedykt XVI napisat wprost w „Deus Caritas est”, że u poczatku bycia chrześcijaninem nie ma wyborów etycznych, nie ma wzniostych idei, jest spotkanie z Osoba, z wydarzeniem, które Jan krótko opisuje „Bóg tak umiłowat świat, że własnego Syna postat”. Myśle, że dzisiaj w takim ogólnym, gtębokim i daleko idacym zamieszaniu tylko Osoba Chrystusa porzqdkuje te sytuacje, bo wszystko inne 
może być niewystarczajace, za słabe. Co dzisiaj można zrobić przez nawotywanie do moralności wśród młodych? Niewiele już można zrobić, można nawoływać, można przypominać, ale i tak niewiele to zmienia, bo młodzi maja swoje doświadczenia. Kilka lat temu Jean Vanier powiedziat, że mniej więcej wszędzie na świecie upadaja tradycje moralne, a to zmusza ludzi do szukania sity większej niż moralność. Tę sitę daje spotkanie z Chrystusem. Zupetnie podobnie, choć bardziej tradycyjnym językiem, mówit o tym ojciec Marie-Dominoque Philippe, założyciel wspólnoty braci św. Jana. Powiedziat, że do zgromadzenia zgłaszaja się młodzi, którzy nie maja wychowania, maja niemal wstręt do cnoty, ale maja powołanie. I kiedy ukaże im się to, co w nich najgłębsze, ich więź przez mitość z Chrystusem, kiedy zacznie się od razu od szczytu, to oni z wolna odkrywaja i sens czystości, i postuszeństwa. W Taizé jesteśmy tego naocznymi świadkami. Podobnie można by spojrzeć na problem tożsamości religijnej, wyznaniowej.

- Jak Brat sądzi: w jakim kierunku może pójść dzieło Brata Rogera, jak Wspólnota widzi swoją przyszłość?

- To bardzo trudne pytanie. Wierzymy w to, że Bóg będzie prowadzit dzieło Brata Rogera. To chyba jedyny sposób. Staramy się też zachować, oczywiście, wierność tej spuściźnie, którq nam zostawił Brat Roger, temu dziedzictwu, które cały czas w Taizé tak naprawdę stale jeszcze odkrywamy. Ale nie chcemy tej spuścizny , konserwować” to nie bytoby po myśli brata Rogera. Zachowujemy więc wierność spuściźnie Brata Rogera, ale i ciagle nastuchujemy Ducha Świętego, patrzqc bez lęku w przyszłość, tak jak robit to Brat Roger.

- Podczas przywitania Jana Pawła II w Taizé w 1992 roku Brat Roger powiedział: „Można przeczuwać, że przyszły wiek będzie wiekiem głębokiej wiary". Skąd wzięło się to przypuszczenie i czy znajduje ono poparcie w doświadczeniach spotkań w Taizé?

- Gdy dzisiaj patrzy się na rzeczywistość takim otwartym spojrzeniem, to można by się lękać, obawiać, bo młodych jest coraz mniej w Kościele. Sa takie miejsca, gdzie nie ma ich wcale. W Polsce też to widać, również w Poznaniu to widzieliśmy. Jednocześnie można zauważyć, że tam, gdzie stworzy się warunki do tego, żeby mogło dokonać się spotkanie z tajemnicq obecności Boga, tam otwieraja się ludzkie serca. Trzeba więc robić wszystko, żeby było jak najwięcej takich możliwości, okazji, przestrzeni, gdzie jest możliwe spotkanie z Chrystusem, który nieustannie podtrzymuje swoje dzieło. Wiara w moc Chrystusa podtrzymuje nas w Taizé: $w$ Jego działanie w świecie, wśród ludzi. Nie wiara w jakaś pedagogikę czy w jakieś metody komunikowania albo w jakieś techniki duszpasterskie czy ewangelizacyjne. Wydaje 
nam się, że bardzo niewiele nieraz potrzeba - kilku ludzi, którzy z wielka prostota i z pokornq wiara coś robia, aby wokół nich zaczęli zbierać się ludzie, którzy poszukuja Boga.

- Czy dostrzegalne jest w Taizé to, o czym dzisiaj się mówi, że żyjemy w erze postchrześcijańskiej, że chrześcijaństwo zaczyna się przeżywać? Czy również Wspólnota zaczyna zauważać zagrożenie rozmycia tożsamości chrześcijańskiej?

- W samym Taizé nie zauważamy tego. Kiedy wyjeżḋamy gdzieś, aby organizować Europejskie Spotkanie Młodych: do Brukseli czy do Genewy, to widzimy oczywiście laicyzację, która można interpretować jako postchrześcijaństwo. A jednocześnie nasze doświadczenie jest takie, że watmosferze modlitwy, ciszy ludzie szukaja Boga. Owo poszukiwanie musi dokonywać sie jednak w wolności, musi być autentyczne. Nie można być nachalnym, wymuszać.

- Czy wynika z tego, że Kościoły instytucjonalne nie przekonują ludzi, że ludzie trochę inaczej szukają Boga, Chrystusa?

- Tak. Można by powiedzieć, że pewne struktury, a w zasadzie ich ociężałość, moga być przeszkoda dla ludzi, zreszta nie tylko młodych. Dlatego szukaja łatwiejszych dróg. Zarzuca się nam czasami, że tworzymy taka łatwiejsza drogę. Ale jednocześnie to wcale nie znaczy, że ludzie odrzucaja kompletnie wymagania. Wielu jest takich, którzy zaznali swobody życia i dzisiaj szukaja porzqdku. Tylko że nowy porzqdek nie może być wracaniem do starych regut, które $w$ dzisiejszym świecie już nie funkcjonujq. Trzeba się odwołać do starego, do tradycji - to jest oczywiste, Brat Alois też mówił o tym w Poznaniu - ale nadać jej też nowy wyraz, aby współcześni ludzie mogli się w niej odnaleźć. Powrót do starych regut może odpowiadać małej grupie osób. Chodzi więc o to, żeby znaleźć formutę uniwersalna, która dla wielu ludzi stworzy przestrzeń poczucia szczęścia, wolności, stabilności, jedności.

- Czy kontrowersje wokół krzyża, które obecnie powstały, są wyrazem agresji wojującej niewiary, czy kwestią chrześcijaństwa, które wypaliło się w ludziach, i chcieliby koniecznie, aby religia była niezobowiązująca, pozbawiona znaku, symbolu i sprowadzona tylko do wymiaru osobistego?

- Moim osobistym zdaniem jest to neopoganizm, który niesie w sobie jaką́s wrogość, ale czy odpowiedziq na to ma być zbrojenie się chrześcijan, czy może powinno niq być bardziej wyraziste życie chrześcijańskie, dla którego fundamentem jest miłość, a krzyż jest wyrazem miłości, czyli również gotowości do ponoszenia ofiary? Rozstrzygnięcie tej kwestii jest trudne, ponieważ nie chodzi o to, aby być naiwnym. Obrona swojej tożsamości, obrona znaku 
i domaganie się wolności sq też ważne. Brat Roger bardzo dobrze to rozumiat, nie byt pacyfista, byt realista, miat głębokie poczucie rzeczywistości, umiat się domagać różnych rzeczy. Nie należy jednak zapominać, że Ewangelia formuje nas do ofiary, do zgody na cierpienie z powodu Ewangelii.

- Mówi się obecnie często o tym, że za kilkadziesiąt lat Europa może być w dużym stopniu islamska. Czy jest tak, że życie nie znosi pustki i gdy chrześcijaństwo się wycofuje, wtedy w to miejsce wchodzi islam ze swoją inwazyjną pobożnością, czy może po prostu Pan Bóg obecnie inaczej prowadzi ludzi?

- Następne nasze spotkanie odbędzie się w Rotterdamie, mieście, w którym 40\% mieszkańców stanowiq muzulmanie i merem miasta jest muzułmanin. Jest to takie pierwsze miasto w Europie.

Nie umiem odpowiedzieć na to pytanie, sq to procesy nowe. Wiem tylko, że strach, lęk na pewno niczego dobrego nie podpowiada. Zamiast bać się, część naszych braci pojechała do krajów islamskich i żyje wśród muzulmanów. Mamy fraternie w dwóch miejscach: w Senegalu i w Bangladeszu. Odkrywamy tam istotę tej religii oraz to, że wiele można zrobić wspólnie.

$W$ Bangladeszu muzulmanie nas broniq - broni nas oczywiście nasza modlitwa, bo muzutmanie ceniq ludzi, którzy się modla. Oni maja stereotyp chrześcijanina, że jest to wierzacy, który nie modli się. Stereotyp ten powstat, poniewaz muzulmanie nie widza modlacych się chrześcijan. Nas natomiast widzq modlacych się, bo wszystko jest tam ażurowe, kaplica jest z bambusa, a bracia spotykaja się trzy razy dziennie na modlitwie. To muzutmanom wystarcza. Bardzo nas tam szanuja i nigdy sie jeszcze nic dla nas groźnego nie zdarzyło. Gdy wybuchaja jakieś zamieszki, to taki stary muzulmanin $z$ sasiedniej wioski przyjeżdża do braci i zamieszkuje z nimi, bo uważa, że bracia to sq ludzie Boży. Wiara nas taczy, a nie dzieli. Mówiq o tym ostatni papieże, że autentyczna wiara łaczy ludzi a nie dzieli. Podziały sq tam, gdzie sa jakieś interesy, gdzie do gry wkracza ideologia. Ale wokót nas sa przede wszystkim ubodzy muzutmanie i ich pokorna wiara. Ona sprawia, że muzutmanie postrzegaja nas jako ludzi Bożych. Gdy umierała jedna stara, uboga muzułmanka, to, co miała, podarowała jednemu z naszych braci.

Bardzo dobry kontakt mamy równiez z niepetnosprawnymi, którymi w Bangladeszu nikt wcześniej nie zajmowat się. W roku jubileuszowym biskup miejscowy poprosit braci, żeby zorganizowali coś dla niepetnosprawnych. To nie byto tatwe, bo wymagato nawiazania licznych kontaktów. Bracia rozpoznali sytuacje niepetnosprawnych $i$ zaczęli organizować dla nich pielgrzymki do miejscowego sanktuarium w górach. Bangladesz jest krajem równinnym, ale gdzieniegdzie można znaleźć tam wzgórza. Bracia obecnie systematycznie tam pielgrzymuja, a muzutmanie im pomagaja, goszcza ich 
u siebie wraz z niepetnosprawnymi, gotuja dla nich ryż. Wiele rzeczy można robić wspólnie.

Serdecznie dziękujemy za rozmowę. Życzymy Bratu i całej Wspólnocie z Taizé wiele światła, sił duchowych i Bożego błogosławieństwa na trud budowania środowiska spotkania w dialogu: modlitwy, ciszy, skupienia i dialogu młodych.

Z Bratem Markiem z Taizé rozmawiali ks. Jerzy Bagrowicz i Jarostaw Horowski

Poznań, 8 stycznia 2010 roku 
